\title{
Towards a Global Digital Constitutionalism: A Radical New Agenda for UN75
}

\author{
Anita Gurumurthy ${ }^{1} \cdot$ Nandini Chami $^{1}$
}

Published online: 3 May 2021

๑) Society for International Development 2021

\begin{abstract}
Twenty years after the WSIS, even as multi-stakeholder governance models in the domain have been stripped of any claim to their democratic potential, global digital governance is in shambles. Norm-building for the digital paradigm is increasingly shifting to plurilateral spaces and private sector-led rule-making in the guise of technical standards development. The UN Secretary-General's Roadmap for Digital Cooperation (2020) has failed to address this crisis. The paper argues for how in its 75th year, the UN needs to make a clean break from its historical soft-pedalling of corporatized rule-making for the digital by embracing the radical agenda of a transformative global constitutionalism, and proceeds to outline its constituent elements.
\end{abstract}

Keywords Global digital cooperation $\cdot$ Big Tech governance $\cdot$ WSIS Plus $20 \cdot$ UN 75

\section{The Digital Epoch}

Seventy-five years ago, like the phoenix rising from the ashes, the United Nations emerged as a beacon of hope in a world reeling from the aftermath of a horrific world warnuclear weapons deployed against civilians, state-sponsored crimes against humanity, and deep impoverishment of colonized countries and peoples in the Global South. The Charter of the United Nations (UN) adopted in 1945 provided the constitutional basis for ushering in a new international order grounded in the three-point agenda of peace and security, human rights and development.

Today, the world stands at the edge of another precipice. In the past two decades, very little progress has been made on reducing inter- and intra-country inequality. ${ }^{1}$ There is extreme centralization of economic power (Esteve 2016), increase in inter-firm inequality (Qureshi 2020), and a global decline in the labour share of national income (Guellec and Paunov 2017). The pandemic is but a grim foreboding of the many ominous consequences that are bound to follow from a growth project gone awry, with a cavalier disregard for planetary boundaries. Digital capitalism has only furthered this unjust and unsustainable paradigm.

Anita Gurumurthy

anita@itforchange.net

1 IT for Change, Bengaluru, India
The trans-border space of flows opened up by the Internet and digital technologies is characterized by platformization, a brand-new mode of capital accumulation (Poell et al. 2019). Based on the capture of networked flows of goods, services, and social interactions, and harnessing of databased intelligence from these flows, digital corporations at the top of the pecking order control emerging global value chains (Gurumurthy et al. 2020). The digital revolution has ushered in a new phase of neoliberal economic globalization, where market power is synonymous with network-data power. Digital intelligence has become the constitutive core of the digital society, and intelligent corporations-known variously as GAFAA, GAFAM, FAANG ${ }^{2}$ and so on-the centrifugal force of economic systems.

The business model of the intelligent corporation, predicated on the enclosure of networked flows and data resources, has led to an economy-wide intensification of

\footnotetext{
${ }^{1}$ It may be true that in the past 25 years, inequality between countries has fallen as average incomes in developing countries are rising. However, the gap between countries continues to be wide. For example, average income in North America is 16 times higher than in sub-Saharan Africa. Income inequality within countries has become worse. Today, $71 \%$ of the world's population lives in countries where inequality has increased. 'Inequality-Bridging the Divide', United Nations, https://www.un.org/en/un75/inequality-bridging-divide, accessed 26 October 2020 .

2 Acronyms used to refer to Big Tech companies Google, Apple, Facebook, Amazon, Alibaba (GAFAA); Google, Apple Facebook, Amazon, Microsoft (GAFAM) and Facebook, Apple, Amazon, Netflix, Google (FAANG).
} 
'winner-take-all' markets and an immense concentration of wealth in the hands of a few (Gurumurthy and Chami 2020). Five digital companies-Apple, Microsoft, Alphabet, Amazon and Facebook-make up 18\% of the total market capitalization as per Standard \& Poor's 500 index, the highest such percentage in history (Levy and Konish 2020). As the United Nations Conference on Trade and Development (UNCTAD) Digital Economy Report 2019 observes, the United States of America (USA) and China account for:

75 per cent of all patents related to blockchain technologies, 50 per cent of global spending on IoT (Internet of Things), and more than 75 per cent of the world market for public cloud computing. And, perhaps most strikingly, they account for 90 per cent of the market capitalization value of the world's 70 largest digital platforms (UNCTAD 2019).

Even as the global economy went into a tailspin after the pandemic, the personal wealth of the owners of Big Tech companies increased manifold. Jeff Bezos, Amazon's Chief Executive Officer, saw his personal fortune increase by over US\$ 40 billion during this period, ${ }^{3}$ while warehouse workers of his company went without health and safety guarantees.

As intelligent corporations use data-based optimization to selectively mobilize and demobilize labour in the value chains they control, permanent jobs are replaced with 'gig work' arrangements unprotected by labour guarantees (Kenney and Zysman 2019). Algorithmic gaming of the digital public sphere by social media giants has led to a viral outrage that systematically circulates hate and misinformation, intensifying political polarization and the degradation of deliberative democracy (Pasquale 2017). As intelligent corporations extend their operations into the real world, subsuming activities across sectors into the apparatus of data, digital capitalism has ushered in a new-age imperialism wherein countries from the Global South are the source of data.

The might of the digital giants, or Big Tech, is sustained not only because of material, network-data power. The centralization and enclosure of digital technological resources, and ascendance of corporate controlled platform infrastructures in the society and economy rest on a compelling myth

\footnotetext{
3 Anthony Cuthbertson, 'Jeff Bezos's Net Worth Passes \$200bn as Pandemic Boosts Wealth of Ultra Rich', The Independent (Independent Digital News and Media, 27 August 2020), https://www. independent.co.uk/life-style/gadgets-and-tech/news/jeff-bezos-networth-richest-person-world-who-amazon-pandemic-a9691491.html, accessed 26 October 2020; FE Online, 'Jeff Bezos Got Richer by $\$ 40$ Billion amid Coronavirus; Here's How Amazon Founder Added Wealth', The Financial Express 16 June 2020, https://www.financiale xpress.com/industry/sme/jeff-bezos-got-richer-by-40-billion-amidcoronavirus-heres-how-amazon-founder-added-wealth/1993288/. Accessed 26 October 2020
}

of how the future of humanity is predicated on unencumbered digital innovation. The parameters of 'development', it is assumed, are best understood by elite corporate actors who are to be left untouched by the stifling tyranny of regulation. This myth rests on a number of discursive planks of corporate hegemony: 'Internet exceptionalism', which holds that the distributed, decentralized and democratic character of the global Internet will be thwarted by any conventional multilateral approach to its governance (Chenou 2014); 'free global data flows', which considers any effort to regulate cross-border flows of data as a potentially fatal blow to informational freedoms on the Internet-mediated global public sphere (Gurumurthy et al. 2017); 'the global community of users', which reframes market interests as freedom, flexibility, convenience and even collaboration, sharing and solidarity for the Internet users of the world (Ritzer and Jurgenson 2010); and 'data for development', which views data extractivist strategies as the magic bullet for development pathways in the digital economy (Gurumurthy and Chami 2019).

The material-discursive ammunition of Big Tech has served its owners well in building a post-democratic world order that, as the rest of this article will demonstrate, has legitimized and perpetrated a dangerously inimical regime of not only extreme concentration of economic power, but also a usurpation by digital corporations of the very space of governance.

\section{The Multilateral System and Digital Governance}

As a techno-social paradigm, the Internet encompasses a propensity for building and nurturing participatory and decentralized communities. Its unique infrastructural property of 'many-to-many' has inspired new communicative cultures (Castells 2018) and alternative knowledge economies (Benkler 2006) that are historically unprecedented.

At the UN World Summit on the Information Society (WSIS) in 2003, the contributions of innumerable creators of what essentially translates into the social experience of the Internet, anchored a new point of departure in imagining its governance. It was acknowledged that "building a people-centred information society is a joint effort which requires cooperation and partnership among all stakeholders'. ${ }^{4}$ A multi-stakeholder approach was seen as the appropriate method for a democratic internationalism of Internet governance, accounting for the differentiated roles and responsibilities of governments, the private sector and civil

\footnotetext{
$\overline{4}$ WSIS Declaration of Principles 2003, Para B1)20. https://www.itu. int/net/wsis/docs/geneva/official/dop.html.
} 
society in addressing the unique technical and public policy dimensions of the issue. To operationalize this vision, a multi-stakeholder Working Group on Internet Governance (WGIG 2005) was set up.

The WGIG tabled its future roadmap for Internet governance at the WSIS Phase-2 Summit in 2005, proposing four institutional models, three of which called for US control over the administration of the Domain Name System to be withdrawn through either supplanting Internet Corporation for Assigned Names and Numbers (ICANN) ${ }^{5}$ or making it accountable to a higher intergovernmental body. The WGIG took the view that Internet-related public policy 'was clearly to be a governmental responsibility with other stakeholders contributing to it' (WGIG 2005; Kruger 2016). The ICANN internationalization agenda was, however, scuttled by the USA, with the European Union (EU) in tow. ${ }^{6}$ The emerging economies-Brazil, Russia, China and India-pushing for greater influence in Internet governance, were still able to score a partial victory, with the insertion of the idea of 'enhanced cooperation in the outcome document', known as the 'Tunis Agenda' (Trinkunas and Wallace 2015).

Para 69 of the Tunis Agenda acknowledges 'the need for enhanced cooperation in the future, to enable governments, on an equal footing, to carry out their roles and responsibilities, in international public policy issues pertaining to the Internet'.

In addition to enhanced cooperation, the Tunis Agenda also provided for the establishment of a multi-stakeholder deliberative forum for the ongoing discussion and debate of Internet-related public policy issues, the Internet Governance Forum (IGF).

Since 2005, the USA and its digital corporations have been able to manufacture and perpetuate a status-quoist Internet governance discourse, arguing for the IGF as the sole route for enhanced cooperation. This, despite the fact that the forum-often referred to as a talk-shop-was never meant to be a space for public policy decision-making. At the World Conference on International Telecommunications

\footnotetext{
${ }^{5}$ ICANN is responsible for Internet address space allocation, protocol identifier assignment, generic and country code Top-Level Domain name system management as well as root server system management functions. Decisions are made through a multi-stakeholder governance model emphasizing international cooperation and inputs from different Internet stakeholders: individuals, non-commercial stakeholder groups, industry and governments. Though ICANN positions itself as an international organization, it is registered in the USA and is subject to US government jurisdiction.

${ }^{6}$ As Lennard G. Kruger (2016) observes, 'conflict at the WSIS Tunis Summit over control of the domain name system was averted by the announcement, on November 15, 2005, of an Internet governance agreement between the United States, the EU, and over 100 other nations. Under this agreement, ICANN and the United States remained in control of the domain name system'.
}

(2012) that examined the possibility of extending the new sets of International Telecommunication Regulations (ITRs) to the Internet, the USA walked out of the discussions, unwilling to allow mention of the 'right of access of Member States to international telecommunication services' in the text. The phrase was intended to restrict arbitrary disconnection of the Internet by the US government for any geopolitical reasons (Singh 2012). A couple of years down the line, at the Net Mundial global multi-stakeholder meeting on the Future of Internet Governance, the US government-despite being under a lot of pressure following the revelations about the National Security Agency's clandestine web of global mass surveillance by Edward Snowden managed to evade the global civil society demand that the outcome document include a reference to the need to govern the Internet as a 'global public good'.

During these important moments in the history of Internet governance contestations, various countries, especially, members of the IBSA group (India, Brazil, South Africa) and China, have emphasized the need to treat multi-stakeholder consultations as a complement to and not substitute for a democratic multilateral framework for the Internet. They have underlined multilateralism as vital for the preservation of digital sovereignty of developing countries. Yet, the US camp has positioned any attempt to change the status quo as a route to an inevitable capture of the Internet by authoritarian, anti-democratic states. Any discussion of intergovernmental cooperation for Internet-related public policy has consequently been mis-framed as an ideological conflict between an Internet that is 'free, open and human rights-based' versus one that is 'balkanized, closed, anti-user and repressive' (Musiani and Pohle 2014). Such mis-framing turns attention away from the realpolitik of geo-political and geo-economic interests of the status-quoists, burying the legitimate concerns of nation-states about preserving their equal stake in Internet governance.

\section{Fragmented Digital Governance and Ineffectual Norm-Making}

Twenty years after the WSIS, even as multi-stakeholder governance models in the domain have been stripped of any claim to their democratic potential, global digital governance is in shambles.

The USA continues to retain considerable control over the Domain Name System, the heart of the Internet, by rejecting

\footnotetext{
7 Third World Network, 'Mixed Reactions to Internet Governance Meeting Outcome', 7 May 2014, https://twn.my/title2/unsd/2014/ unsd140503.htm. Accessed 26 October 2020.
} 
all calls for internationalization and jurisdictional immunity for ICANN. ${ }^{8}$

Cyber security policies have followed two pathways, intergovernmental and multi-stakeholder. The former has been fraught because of a face-off, mainly between the USA and Russia. As a result, two different institutional mechanisms (the Open-ended Working Group on International Cybersecurity mooted by Russia, and the Group of Governmental Experts backed by the USA) have been approved by the UN General Assembly (Ruhl et al. 2020). The Paris Call for Trust and Security in Cyberspace, launched in 2018 by the French government with support from Microsoft, has been endorsed by over 70 countries, 600 companies and private sector entities and 350 civil society organizations, but did not get support from the USA, India, Russia and China. ${ }^{9}$

In the absence of a clear global mechanism for binding multilateral consensus on digital governance, norm-building for the digital paradigm is increasingly shifting to plurilateral spaces (such as the Organisation for Economic Cooperation and Development (OECD) Committee on Digital Economy), and private sector-led rule-making, through bodies such as the World Economic Forum (WEF). The NetMundial Initiative, a joint initiative that the ICANN and the WEF launched in November 2014, was the flagbearer of privatized norm-setting in the global digital governance space (Pohle 2015). The door it opened for legitimizing the private sector's right to claim an equal seat with governments in digital policymaking remains wide open.

For instance, in 2018 the WEF launched the Earth Bank of Codes that will serve as a blockchain-based register of global biological and biomimetic intellectual property assets. ${ }^{10}$ The intent is to create a global mechanism that enables commercial appropriation of these resources through a transparent trading system that, ostensibly, prevents biopiracy by corporations. However, historical evidence suggests that the commercial use of biodiversity commons has seldom brought benefits to local communities. It therefore seems likely that a new wave of marketization of biological resources through an 'open access' digital and data framework may easily end up upending the prior right of indigenous communities to their natural habitat and knowledge

\footnotetext{
${ }^{8}$ In October 2016, the USA did transfer the oversight of the Domain Name System from the National Telecommunications and Information Administration to ICANN. But it refused to accept any proposal that calls for the internationalization of ICANN that would ensure its jurisdictional immunity. This means that in practice the global Internet community continues to be at the mercy of US government decisions about internet operations. For example, consider the recent seizure of Iranian domain names by the FBI.

9 'Paris Call for Trust and Security in Cyberspace', Paris Call, https://pariscall.international/en/. Accessed 26 October 2020.

${ }^{10}$ Earth Bank of Codes, https://www.earthbankofcodes.org/. Accessed 26 October 2020.
}

traditions. Lacking a democratic governance framework, the initiative effectively corporatizes the data wealth pertaining to the world's natural resources.

In June 2019, the WEF and the UN inked a Strategic Partnership Framework to accelerate the implementation of the sustainable development goals through cross-organizational engagement in six core areas, including digital cooperation. ${ }^{11}$ One of the key objectives of this collaboration is 'to meet the needs of the Fourth Industrial Revolution through global analysis, dialogue and standards for digital governance and digital inclusiveness'. The rhetoric of inclusion notwithstanding, the stage seems to be all set for private capture of global digital governance (Gleckman 2019).

As the digital becomes the driver of economic globalization, trade policy arenas have emerged as key among the proliferating sites of digital public policy and governance contestations. To sustain and expand global market access for its digital corporations, the USA has used multilateral and plurilateral trade negotiations to push for free crossborder data flows, an agenda that developing countries have held has no place in trade policy (James 2020). At the same time, the USA has consistently blocked international and national efforts to tax transnational digital corporations, even threatening retaliatory trade sanctions. ${ }^{12}$ Also, in its domestic technology market, the USA regulates market access of foreign corporations (particularly Chinese) through strict investment scrutiny mechanisms - an act of clear hypocrisy, as it is this very policy space that it denies other governments who are party to its free trade agreements. Similarly, the Clean Network initiative announced by the US Secretary of State in August 2020 to block Chinese telecommunications carriers, app providers and cloud services from the US market is reminiscent of the digital balkanization that it has decried on many occasions. ${ }^{13}$

The exponential growth of technical and regulatory issues in Internet governance in the last decade, thanks to the rapid advances in data, artificial intelligence (AI), blockchain and Internet of Things (IoT) technologies, has widened and

\footnotetext{
11 The Strategic Partnership will focus on the following areas: Financing the 2030 Agenda, climate change, health, gender equality and empowerment of women, education and skills and digital cooperation. 'World Economic Forum and UN Sign Strategic Partnership Framework', World Economic Forum, 13 June 2019, https://www. weforum.org/press/2019/06/world-economic-forum-and-un-sign-strat egic-partnership-framework/. Accessed 26 October 2020.

12 'USTR Opens New Investigations into Digital Services Taxes', Deloitte tax@hand, 6 June 2020, https://www.taxathand.com/article/ 13725/Indonesia/2020/USTR-opens-new-investigations-into-digitalservices-taxes. Accessed 26 October 2020.

13 Announcing the Expansion of the Clean Network to Safeguard America's Assets, Michael Pompeo, Secretary of State, 5 August 2020, https://www.state.gov/announcing-the-expansion-of-the-cleannetwork-to-safeguard-americas-assets/. Accessed 26 October 2020.
} 
deepened this governance crisis. Big Tech has usurped crucial public interest functions through de facto control over platform infrastructures and standards setting, like digital identification (Burt 2020) and payment systems (Browne 2020). Privately controlled virtual currency initiatives have displaced the public function of money, hitherto regulated by central banks accountable to citizens (European Parliament 2019). The inscrutability of corporatized AI as de facto law presents a worrisome prognosis. Digital gene sequencing, for instance, is a veritable blackbox that Big Pharma holds secret. Given the dual-use nature ${ }^{14}$ of both digital and gene technologies, the lack of a democratically debated global benchmark in the bioinformatics domain presents a real threat to the security and well-being of planet and people alike (Pauwels 2019).

Viral misinformation and hate in recent history, including the Rohingya crisis in Myanmar, Christchurch shootings in New Zealand and the US presidential elections, have accelerated the anxieties about the unprecedented power of social media giants in determining public sphere protocols. This has galvanized various initiatives for voluntary and private rule-making such as the Santa Clara principles on transparency and accountability in content moderation,,${ }^{15}$ and Facebook's content oversight board. The protocol power of social media companies is also evidenced in various techno-design tweaks, including Instagram's 'restrict' mode to counter cyberbullying, and Facebook's 'lock-your-profile' safety feature for women in India. American social media companies, however, continue a policy of expediency, adopting an inconsistent-by-choice approach in different jurisdictions, selectively defining the limits to free speech according to their business interests (Marantz 2020).

With Big Tech corporations extending their monopoly control through integration of multi-sector vertical markets (e.g., Amazon has branched out from e-commerce into health and pharma, digital streaming, and robotics) and data-based horizontal markets (that is, Amazon is not only a data collector, but also cloud and analytics provider), norm- and rule-making in the digital arena is in the throes of a major shift. This is represented in the hollowing out of public infrastructures, not simply through privatization, but a systemic socialization of privately controlled platforms. The platformization epoch in the digital society hence represents a de-democratization and de-publicization of governance. The private platform and its constituent functionalities are

\footnotetext{
${ }^{14}$ Implying the possibility of use of a technology both for civil and military purposes.

15 Santa Clara Principles on Transparency and Accountability in Content Moderation, Santa Clara Principles, https://santaclaraprinc iples.org/. Accessed 26 October 2020.
}

the public protocols, and the data-based intelligence that powers it is the law.

This shifting terrain of power has ushered in what has been referred to as a new bipolar world, with China's rise as a new AI superpower. China has historically pursued a different route to digital capability-digital and data sovereignty to expand domestic digital industry, and export of surplus industrial output through e-commerce (UNECA 2019). In the post-COVID-19 context, through its 'Digital Silk Road' initiative, the country has sought to export advanced technologies such as $5 \mathrm{G}$ and facial recognition (Triolo and Greene 2020). Chinese Big Tech companies are also establishing supply chains in agriculture, dairy, and retail commerce, extending their markets, in the South East Asian region. ${ }^{16}$ The fourth industrial revolution thus presents a Hobson's choice in which countries may be forced to choose between US and Chinese corporations for access to advanced digital prowess.

It remains to be seen how the EU's recent policy initiatives on data and AI infrastructure sovereignty can shift the vectors of geo-economic power. The prospects for developing countries, however, seem enormously challenging, if not bleak.

\section{Towards a New Global Digital Constitutionalism}

As the UN Secretary-General acknowledged in 2019, the multilateral system is 'unprepared and needs to catch up' to face the challenges of the age of digital interdependence. ${ }^{17}$ Democratic mechanisms for furthering enhanced cooperation' between nation states, private sector and civil society envisaged by the WSIS have failed to materialize. Technical governance of the 'embedded infosphere' (Taylor 2017) is marketized, with powerful US and Chinese companies leading the way for the infrastructuralization of Internet, data and platform technologies. The socialization of the digital has meant the default socialization of corporate rule-setting, reminiscent of Karl Polanyi's 'market society', whereby social relations are embedded in the market economy. A rapidly growing laissez faire digital economy is a prime site of US hegemonic power, consolidated through the ideology of 'free data flows' in trade deals. Fragmented, inchoate

\footnotetext{
${ }^{16}$ Bloomberg, 'Coronavirus: Alibaba's Lazada Seizes Opportunity to Expand Grocery Sales', South China Morning Post, 20 October 2020, https://www.scmp.com/news/asia/southeast-asia/article/30843 21/coronavirus-alibabas-lazada-expands-grocery-sales-asia. Accessed 26 October 2020

17 'UN Makes 'Declaration of Digital Interdependence', with Release of Tech Report', United Nations, 10 June, https://news.un.org/en/ story/2019/06/1040131. Accessed 26 October 2020.
} 
and even missing in most parts, global digital governance represents a complex equilibrium managed by Big Tech as arbitrator and adjudicator of societal interaction, economic activity and political processes. The resultant institutional crisis of democracy and rule of law has grave repercussions for people and planet, as discussed earlier. An urgency like never before stares us at the UN75 moment to rescue the 'respect for the principle of equal rights and self-determination of peoples', and cherished value of 'peace', exhorted by Article 2 of the UN Charter.

The evolving domain of digital rights demands deeper scrutiny in this context. The Human Rights Council has urged the preservation of the global and open nature of the Internet, international digital cooperation to support information and communication technology (ICT) infrastructurebuilding in all countries, and the adoption of a democratic and human rights-based approach to the governance of digital technologies (UNGA HRC 1 2018a). The Special Rapporteur on the Right to Freedom of Opinion and Expression has called attention to how corporate-led content governance is ineffectual in addressing misinformation, hate speech, and the erosion of democracy in the digital public sphere (UNGA HRC 2 2018b), and 'how the private sector's focus on, and the public sector's push for, ethics' is an escape route for evading human rights-based, binding regulation of emerging AI technologies (UNGA 2018c).

The Special Rapporteur on the Right to Privacy has pointed to how personal data processing sans 'safeguards without borders' and 'remedies across borders' poses unprecedented challenges to the right to privacy in the age of ubiquitous personal data processing (Cannataci 2016). The former Special Rapporteur on Extreme Poverty and Human Rights has warned that in order to address the erosion of the right to social protection and the impunity of technology corporations in the emerging digital welfare state, a new approach to data and AI governance that privileges human autonomy over market considerations is urgently needed (UNGA 2019).

A critical discourse pointing to wide-ranging normative deficits, specifically in the regulation of digital technologies, and generally in rights-based governance for the digital age, is emerging in the human rights system. It suggests that the absence of a universal political constitutionalism adequate to the human condition in the current techno-social epoch is untenable. Unfortunately, the multilateral system, in its current form, is unable to meaningfully translate such emerging recommendations into effective on-the-ground action. The digital cooperation agenda, as actionized through multi-stakeholder alliances, has become yet another instance of 'neoliberal lock-in', where the trope of 'technology for development' often masks the workings of the global political economy (Schwöbel-Patel 2017). 'Partnerships' in this regard are but a neocolonial route for opening up market access to data resources of the Global South (WEF and PwC 2020).

Nominalist constitutionalism ignores global distributive justice (WEF and PwC 2020), even as it paves the way for neoliberal 'constitutionalization of the economy' (rules to accelerate financialization and capitalist globalization) at the expense of 'constitutionalization of politics' (rules through which the global community of nations and peoples can aspire to equality and justice) (Guimarães 2019). The EU makes for an interesting analysis in this regard. The rise of US Big Tech has seen EU digital economy policies increasingly focus on anti-competitive behaviour by digital companies. Its data strategy aims at restoring a level playing field for innovation in the European data market. While the EU's General Data Protection Regulation offers its citizens protections from privacy violations and discriminatory data processing, it may be argued that this protection itself is contingent on keeping data separate from human bodies, in order to balance the rights of human beings and digitalized flows for the purposes of digital capitalism (Käll 2017). Also, the adequacy determination rules ${ }^{18}$ that the EU deploys in its trade deals instrumentalizes the political right to privacy and data protection for the purposes of economic efficiency. In global trade discussions, the EU has gone with the US position of unrestricted data flows, impervious to the autonomy that developing countries need to steer the digital economy towards their own socio-economic development.

Global constitutionalism has also been rightly critiqued for a preoccupation with anthropocentricism, ignoring alternative visions and values through which communities in the Global South relate to their environment. Indigenous people's movements fighting extractive capitalism have time and again underlined this ecological blind spot, arguing that universal justice can be achieved only if attention is paid to the connections between the market, power and rule-making. The 'carbon credit' model of greening the digital economy helps Big Tech companies such as Microsoft score points for commitments to carbon negativity while deepening its links with destructive oil and gas mining operations. As Greenpeace observes in a 2020 report,

Microsoft seems to have the most contracts with oil and gas companies and offers AI solutions for all phases of oil production. A contract between Microsoft and ExxonMobil alone could result in additional annual emissions of 3.4 million metric tons $\mathrm{CO} 2 \mathrm{e}$, the equivalent of more than 20 percent of Microsoft's total

\footnotetext{
18 The European Commission has the power to determine, on the basis of article 45 of Regulation (EU) 2016/679 whether a country outside the EU offers an adequate level of data protection. The effect of such a decision is that personal data can flow from the EU to a third country without any further safeguard being necessary.
} 
annual carbon footprint. Amazon primarily has contracts for pipelines, shipping and storage for oil and gas companies. And the Amazon Web Services (AWS) cloud is the largest in the world and is used by oil and gas companies to bring oil to market more efficiently (Greenpeace 2020).

The empirical reality of multilateral constitutionalization calls into question the depoliticization of the economy and the questionable legitimacy of current global institutions. However, the constitutionalist vocabulary still remains a powerful hermeneutic device, with a much-needed critical and accountability potential that can compensate for globalization-induced constitutionalist deficits at the national level (Peters 2009). People's movements calling for a UN Binding Treaty on Transnational Corporations and Other Business Enterprises with respect to Human Rights have demonstrated the necessity and plausibility of both thinking global and thinking constitutional.

The digital domain is also marked by certain specificities that point to the imperative for a global constitutionalist framework. First, Big Tech platforms, as argued, have consolidated their position in the economy as monopoly players in control of critical technical infrastructures and valuable data resources. The exponential growth in the shares of GAFAM in undersea cable building points to a real threat of fragmentation in the architecture of the Internet (Huston 2016).

Second, the digital paradigm binds together the global Internet and everything that it mediates with Big Data analytics, cloud computing, the Internet of Things and AI systems. Governance in the digital age then is not merely about technical governance of the parts, but normative and institutional governance of the many systemic wholes constituted by the parts that disrupt social, economic and political systems on a planetary scale. The traditional regulatory powers of nation states are already under strain, with developing countries in particular facing many challenges in digital governance. The need for a 'meta-legal system' (De Gregorio and Radu 2020) through which norms with global implications may be produced and shaped cannot be over-emphasized.

Third, the rise in authoritarianism and increased state control of the Internet within national borders is of particular concern. The case of Internet shutdowns is an extreme example of states relying on network architecture to assert their control over the digital environment (De Gregorio and Stremlau 2020). While this may be truer for authoritarian regimes than for others, the global spread of political polarization and right-wing nationalism underscores an urgent need for digital norming that can thwart the vitiation of the public sphere and persecution of the already vulnerable, including by state institutions.
The need of the hour is a global digital constitutionalism, one that is adequate to the emancipatory potential of the digital paradigm and demonstrating continuities with reinvigorated national constitutions. The dominant rhetoric has technicalized digital governance. The World Bank for instance has called for 'international regulatory cooperation' as a method to strengthen the digital economy through the development of principles in areas such as taxation, cybercrime and cybersecurity; privacy and data protection; market competition; Intellectual Property; and data sharing and interoperability (World Bank 2020). While these are indeed significant areas for digital norm development, an exclusive focus on market shaping and regulation before laying out the socio-political constitutional essence of a digitalized world order amounts to a cart-before-the-horse faux pas. It also detracts from a more fundamental, critical assessment of humanity's shared present and future.

A vision for a global digital constitution needs to be embedded in at least three basic norms, or ' grundnorms'. ${ }^{19}$ First, the digital marks an epochal turn, and hence, values and norms need an openness that without sliding into infinite relativism can embrace a constitution-in-the-making approach. The varied implications of frontier technologies in their entanglements with everyday life are only just about becoming clear. The institutional ethics of AI applications in different domains, for instance, will need continuous assessment. The constitutional basis of limitation of powers, rule of law, fundamental rights and democracy may therefore be envisioned as an evolving process, something that must be seen as always 'perfectable' (Rosenfeld 2014).

Second, the digital paradigm must be grounded in a right to participatory and discursive democracy of all peoples. In 2013, the African Union proposed the creation of an International Constitutional Court for the protection of 'the right to democracy' (Carducci and Amaya 2016). Centring people's power for a decentralized world order, this proposal is noteworthy for its departure from state-centric rule-making, advancing "both the justiciability and accountability of governments and national justice systems and the protection of democratic practices of deliberative participation and social inclusion' (Carducci and Amaya 2016). The right to democracy as the basis of the digital paradigm shifts the debate from narrow, state-centric territorial sovereignty to a broader, people's sovereignty. The architecture of the Internet also provides the material possibilities to harness participation through 'global public reason' (Cohen 2004) that is, a shared set of values and norms that binds a global community of peoples.

\footnotetext{
19 The basic norm, order or rule that forms an underlying basis for a legal system.
} 
Third, cyberspace is neither a part of the global commons (like the high seas, outer space or international air space) nor a completely domestic domain, but a mixed common pool of resources (Shackelford 2013). Understood this way, global digital constitutionalism can pave the way for polycentric governance, and by extension, nested citizenship possibilities in the long run.

Developing a global constitution to dismantle the network-data complex and enable the flourishing of people and planet will need an extended timeline. However, the digital juggernaut demands that this process go hand-in-hand with the articulation of governance frameworks at the multitudinous intersections of technology and global public policy. These two processes-one, constitutional and the other, administrative-need not be seen as conflicting; rather, they can catalyze healthy deliberative spaces to reimagine humanity's collective futures. There is a need to ensure that multilateralism is able to keep pace with digital technological advancement, providing normative frameworks across sectors-furthering equality, promoting distributive justice and safeguarding individual and collective rights.

In this regard, the suggestion in the UN SecretaryGeneral's Roadmap for Digital Cooperation (2020) that the Office of the United Nations High Commissioner for Human Rights (UNHCHR) develop system-wide guidance on human rights, due diligence and impact assessments pertaining to the adoption of emerging technologies ${ }^{20}$ is a useful step towards the articulation, coordination and integration of digital governance principles across multilateral UN bodies. Other recommendations in the Roadmap to overhaul the IGF and to create a multi-stakeholder process for Artificial Intelligence cooperation, ${ }^{21}$ however, do not make the cut. Offering no concrete solution to the gaping constitutional crisis in global digital governance, they seem to offer a cure that is worse than the disease-legitimizing corporate rulemaking through the slippery slope of advice, guidance and capacity building.

A shared, peaceful future for a thriving people and planet requires that the idea of 'prosperity' and meaning of 'partnership' be redefined in what inherently is an unjust global system of neoliberal digital capitalism that has led our societies to the brink of collapse. The unprecedented potential of the digital exhorts that our quest for digital governance mechanisms is nothing short of transformative. In its 75 th year, the UN must step up and dream big. A radical point of departure would be for the UN to set up a body on Digital

\footnotetext{
20 'Secretary-General's Roadmap for Digital Cooperation', United Nations, https://www.un.org/en/content/digital-cooperation-roadmap/. Accessed 26 October 2020.

21 'Secretary-General's Roadmap for Digital Cooperation', United Nations, https://www.un.org/en/content/digital-cooperation-roadmap/. Accessed 26 October 2020
}

Issues that can reclaim the unfinished business of enhanced cooperation mandated by the WSIS.

In the WSIS Plus 10 review in 2015, developing countries focused on this mandate, following which the Working Group on Enhanced Cooperation earlier set up by the UN Commission on Science and Technology for Development was given a second term. The Group disbanded in 2018 without consensus. Paradoxically, the OECD countries that dismissed the need for any such multilateral cooperation platform during the Working Group deliberations have been more than willing to discuss and frame public policies for Internet and emerging data and AI technologies at the OECD Committee on Digital Economy Policies.

The new UN body on Digital Issues should kickstart the process of democratic deliberations towards building a global digital constitution. The WSIS Plus 20 milestone in 2025 can present the world community of peoples and nations with a transformative constitutionalism for the digital human condition, carrying the promise of multi-scalar citizenship, and a right of people to claim it as a living document that they can shape and reshape.

Will the phoenix rise again?

\section{References}

Benkler, Yochai. 2006. The Wealth of Networks: How Social Production Transforms Markets and Freedom. New Haven: Yale University Press.

Browne, Ryan. 2020. Big Tech Will Push Deeper into Finance This Year - but Avoid the 'Headache' of Being a Bank, CNBC, 3 January, https://www.cnbc.com/2020/01/03/big-tech-will-push-intofinance-in-2020-while-avoiding-bank-regulation.html, Accessed 26 October 2020

Burt, Chris. 2020. Biometrics Industry Urges Support for PublicPrivate Partnerships in ID4Africa Webinar, Biometric Update, BiometricUpdate.com, 25 June, https://www.biometricupdate. com/202006/biometrics-industry-urges-support-for-public-priva te-partnerships-in-id4africa-webinar, Accessed 26 October 2020.

Cannataci, Joseph A. 2016. Statement by Mr. Joseph A. Cannataci, Special Rapporteur on the Right to Privacy, at the 31st Session of the Human Rights Council, 9 March.

Carducci, Michele, and Lídia Patrícia Castillo. Amaya. 2016. Nature as 'Grundnorm' of Global Constitutionalism: Contributions from the Global South. Revista Brasileira de Direito 12(2): 154-165. https://doi.org/10.18256/2238-0604/revistadedireito.v12n2 p154-165.

Castells, Manuel. 2018. Networks of Outrage and Hope: Social Movements in the Internet Age. Cambridge, UK: Polity Press.

Chenou, Jean-Marie. 2014. From Cyber-Libertarianism to Neoliberalism: Internet Exceptionalism, Multi-Stakeholderism, and the Institutionalisation of Internet Governance in the 1990s. Globalizations 11(2): 205-223. https://doi.org/10.1080/14747731.2014. 887387.

Cohen, Joshua. 2004. Minimalism About Human Rights: The Most We Can Hope For? Journal of Political Philosophy 12(2): 190-213. https://doi.org/10.1111/j.1467-9760.2004.00197.x. 
De Gregorio, Giovanni, and Nicole Stremlau. 2020. Internet Shutdowns and the Limits of Law. International Journal of Communication 14: 1-19.

De Gregorio, Giovanni, and Roxana Radu. 2020. Fragmenting Internet Governance: Digital Sovereignty and Global Constitutionalism. MediaLaws, 16 July. http://www.medialaws.eu/fragmenting-inter net-governance-digital-sovereignty-and-global-constitutionalism/.

Esteve, Ferran. 2016. Technology and Inequality. The Concentration of Wealth in the Digital Economy, February 7. http://lab.cccb.org/ en/technology-and-inequality-the-concentration-of-wealth-in-thedigital-economy/. Accessed 26 October 2020.

European Parliament, Committee on Economic and Monetary Affairs. 2019. The Future of Money: Compilation of papers. Luxembourg: European Union.

Gleckman, Harris. 2019. How the United Nations Is Quietly Being Turned into a Public-Private Partnership. openDemocracy, 2 July. https://www.opendemocracy.net/en/oureconomy/how-united-natio ns-quietly-being-turned-public-private-partnership/?source=inarticle-related-story. Accessed 26 October 2020.

Greenpeace. 2020. Oil in the Cloud How Tech Companies Are Helping Big Oil Profit from Climate Destruction, 19 May. https://www. greenpeace.org/usa/reports/oil-in-the-cloud/. Accessed 26 October 2020 .

Guellec, Dominique, and Caroline Paunov. 2017. Digital Innovation and the Distribution of Income. NBER Working Paper Series Paper No. 23987, November. https://doi.org/10.3386/w23987.

Guimarães, Guilherme Cintra. 2019. Global Technology and Legal Theory: Transnational Constitutionalism, Google and the European Union. Abingdon, Oxon: Routledge.

Gurumurthy, Anita, and Nandini Chami. 2020. The Intelligent Corporation: Data and the Digital Economy. Longreads, 24 September. https://longreads.tni.org/stateofpower/the-intelligent-corporationdata-and-the-digital-economy. Accessed 26 October 2020.

Gurumurthy, Anita, and Nandini Chami. 2019. The Wicked Problem of AI Governance, Artificial Intelligence in India 2 October. http:// library.fes.de/pdf-files/bueros/indien/15763.pdf. Accessed 26 October 2020

Gurumurthy, Anita, Nandini Chami, and Amrita Vasudevan. 2017. The Grand Myth of Cross-border Data Flows in Trade Deals. IT for Change, December. https://itforchange.net/index.php/grandmyth-of-cross-border-data-flows-trade-deals. Accessed 26 October 2020 .

Gurumurthy, Anita, Nandini Chami, Deepti Bharthur, and Vinay Narayan. 2020. Unskewing the Data Value Chain-A Policy Research Project for Equitable Platform Economies Background Paper. September. https://itforchange.net/sites/default/files/1805/ IT $\% 20$ for $\% 20$ Change $\% 20-\% 20$ Concept $\% 20$ note $\% 20$ - $\% 20$ Uns kewing\%20the\%20data\%20value\%20chain.pdf

Huston, Geoff. 2016. The Death of Transit? Web log. APNIC (blog), 28 October. https://blog.apnic.net/2016/10/28/the-death-of-trans it/. Accessed 26 October 2020.

James, Deborah. 2020. Digital Trade Rules: A disastrous new constitution for the global economy written by and for Big Tech. Brussels: Rosa Luxemburg Stiftung.

Käll, Jannice. 2017. A Posthuman Data Subject? The Right to Be Forgotten and Beyond. German Law Journal 18(5): 1145-1162. https://doi.org/10.1017/s2071832200022288.

Kenney, Martin, and John Zysman. 2019. Work and Value Creation in the Platform Economy. Essay. In Work and Labor in the Digital Age (Research in the Work of Sociology, Vol. 33), Steve P. Vallas and Anne Kovalainen (eds.), 13-41. Bingley, UK: Emerald Publishing.

Kruger, Lennard G. 2016. Internet Governance and the Domain Name System: Issues for Congress. Washington, D.C.: Library of Congress, Congressional Research Service.
Levy, Ari, and Lorie Konish. 2020. The Five Biggest Tech Companies Now Make up $17.5 \%$ of the S\&P 500 - Here's How to Protect Yourself, CNBC 28 January 28, https://www.cnbc.com/2020/01/ 28/sp-500-dominated-by-apple-microsoft-alphabet-amazon-faceb ook.html. Accessed 26 October 2020

Marantz, Andrew. 2020. Why Facebook Can't Fix Itself. The New Yorker, 12 October. https://www.newyorker.com/magazine/2020/10/ 19/why-facebook-cant-fix-itself. Accessed 26 October 2020.

Musiani, Francesca, and Julia Pohle. 2014. NETmundial: Only a Landmark Event If 'Digital Cold War' Rhetoric Abandoned. Internet Policy Review. https://doi.org/10.14763/2014.1.251.

Pasquale, Frank. 2017. The Automated Public Sphere. New York: Rosa Luxemburg Stiftung.

Pauwels, Eleonore. 2019. The Geopolitics of Converging Risks: The $U N$ and Prevention in the Era of AI. United Nations University Centre for Policy Research.

Peters, Anne. 2009. The Merits of Global Constitutionalism. Indiana Journal of Global Legal Studies 16(2): 397. https://doi.org/10. 2979/gls.2009.16.2.397.

Poell, Thomas, David Nieborg, and José Van Dijck. 2019. Platformisation. Internet Policy Review. https://doi.org/10.14763/2019.4. 1425.

Pohle, Julia. 2015. Multistakeholderism Unmasked: How the NetMundial Initiative Shifts Battlegrounds in Internet Governance. Global Policy Journal, 5 January. https://www.globalpolicyjournal.com/ blog/05/01/2015/multistakeholderism-unmasked-how-netmu ndial-initiative-shifts-battlegrounds. Accessed 26 October 2020.

Qureshi, Zia. 2020. Inequality in the Digital Era. Essay. In Work in the Age of Data, edited by BBVA Openmind. Turner Libros.

Ritzer, George, and Nathan Jurgenson. 2010. Production, Consumption, Prosumption: The Nature of Capitalism in the Age of the Digital Prosumer. Journal of Consumer Culture 10(1): 13-36.

Rosenfeld, Michael. 2014. Is Global Constitutionalism Meaningful or Desirable? European Journal of International Law 25(1): 177199. https://doi.org/10.1093/ejil/cht083.

Ruhl, Christian, Duncan Hollis, Wyatt Hoffman, and Tim Maurer. 2020. Cyberspace and Geopolitics: Assessing Global Cybersecurity Norm Processes at a Crossroads. Carnegie Endowment for International Peace and Perry World House Working Paper, February.

Schwöbel-Patel, Christine. 2017. The Political Economy of Global Constitutionalism. Essay. In Anthony F. Lang and Antje Wiener (eds.), Handbook on Global Constitutionalism. Cheltenham, UK: Edward Elgar Publishing.

Shackelford, Scott J. 2013. Toward Cyber Peace: Managing Cyber Attacks Through Polycentric Governance. American University Law Review 62(5): 1273-1364.

Singh, Parminder Jeet. 2012. A False Consensus Is Broken, The Hindu, 20 December, https://www.thehindu.com/opinion/lead/a-falseconsensus-is-broken/article4222688.ece, Accessed 26 October 2020.

Taylor, Richard D. 2017. The next Stage of U.S. Communications Policy: The Emerging Embedded Infosphere. Telecommunications Policy 41(10): 1039-1055. https://doi.org/10.1016/j.telpol. 2016.11.007.

Trinkunas, Harold A., and Ian Wallace. 2015. Converging on the Future of Global Internet Governance: the United States and Brazil. Washington, D.C.: Foreign Policy at Brookings.

Triolo, Paul, and Robert Greene. 2020. Will China Control the Global Internet via Its Digital Silk Road? SupChina, 30 June. https:// supchina.com/2020/05/08/will-china-control-the-global-internetvia-its-digital-silk-road/.

UNCTAD. 2019. Digital Economy Report 2019: Value Creation and Capture: Implications for Developing Countries. Geneva: United Nations. 
United Nations Economic Commission for Africa (UNECA), Office of the High Commissioner for Human Rights, and Friedrich-EbertStiftung. 2019. Digital Trade in Africa: Implications for Inclusion and Human Rights.

United Nations General Assembly (UNGA). 2019. Extreme poverty and human rights-Report of the Special Rapporteur on extreme poverty and human rights. A/74/493. 11 October.

United Nations General Assembly, Human Rights Council (UNGA HRC 1). 2018a. The Promotion, Protection and Enjoyment of Human Rights on the Internet. A/HRC/38/L.10/Rev.1. 1 July.

United Nations General Assembly, Human Rights Council (UNGA HRC 2). 2018b. Report of the Special Rapporteur on the promotion and protection of the right to freedom of opinion and expression. A/HRC/38/35. 6 April.

United Nations General Assembly (UNGA). 2018c. Promotion and protection of the right to freedom of opinion and expression-Note by the Secretary-General. A/73/348. 29 August.
Working Group on Internet Governance (WGIG). 2005. Report of the Working Group on Internet Governance. Château de Bossey.

World Bank. 2020. World Development Report 2021: Data for Better Lives-Concept Note. May.

World Economic Forum, and PwC. 2020. Unlocking Technology for the Global Goals. Geneva: World Economic Forum.

Publisher's Note Springer Nature remains neutral with regard to jurisdictional claims in published maps and institutional affiliations. 